\title{
PRAEMURGELLA VALENCIANA NOV. GEN. ET SP. (FORAMINIFERA) IN THE SIERRA DE UTIEL FORMATION (CONIACIAN-SANTONIAN) OF THE PREBETIC DOMAIN (SE SPAIN)
}

\author{
ELENA LUPERTO SINNI, JAVIER MARTÍN-CHIVELET \& Rocío GIMÉNEZ
}

\begin{abstract}
Micropaleontological and biostratigraphical examination of Upper Cretaceous shallow marine carbonates outcropping in the Sierra de la Solana near the town of Bocairent (SE Spain) permitted the identification of numerous specimens of a new species of Foraminifera. To date, the genus of this species is unknown. Based on the detailed analysis of non-orientated thin sections, the new genus and representative new species were defined. The morphological and structural features of Praemurgella valenciana nov. gen. et sp. permit its interpretation as a primitive species related to Murgella lata LuPERTO SinNI, 1965, from which the name of the new genus was derived. Further, due to its biostratigraphical location restricted to a few meters within thick, monotonous inner-shelf successions of Betic carbonate platforms, this new species is considered to be a good chronobiostratigraphic marker corresponding to a mid Santonian age.
\end{abstract}

KEYWORDS: PRAEMURGELLA VALENCIANA NOV. GEN. ET SP., LATE CRETACEOUS, PREBETIC, CARBONATE PLATFORMS, SANTONIAN.

RÉSUMÉ - L'étude micropaléontologique et biostratigraphique de la succession crétacée à calcaires de plate-forme peu profonde de la Sierra de la Solana, proche de la ville de Bocairent (Province de Valence, SE de l'Espagne) a permis de collecter de nombreux exemplaires d'une nouvelle espèce de foraminifère, qui appartient également à un genre nouveau. L'analyse détaillée de ces exemplaires, basée exclusivement sur lames minces, a permis de définir le genre nouveau et l'espèce qui le représente. La définition de Praemurgella valenciana nov. gen. et sp. a une grande importance par deux raisons: (1) du point de vue systématique, ses caractères morphologiques et structuraux situent P. valenciana comme une espèce primitive par rapport à Murgella lata LUPERTO SINNI, 1965, de laquelle dérive le nom du nouveau genre; (2) du point de vue biostratigraphique, l'espèce est limitée à quelques mètres dans l'épaisse, continue et monotone succession carbonatée de la plate-forme bétique d'âge coniacien-santonien, fait qui suggère que $P$. valenciana peut être considerée comme un excellent marqueur chronobiostratigraphique, indicatif d'un âge santonien moyen.

MOTS-CLÉS: PRAEMURGELLA VALENCIANA NOV. GEN. ET SP., CRÉTACÉ SUPÉRIEUR, PLATES-FORMES CARBONATÉES , PRÉBÉTIQUE, SANTONIEN.

RIASSUNTO - Le analisi micropaleontologiche e biostratigrafiche di una successione di rocce carbonatiche in facies di piattaforma, affiorante nella Sierra della Solana, in prossimità della città di Bocairent (SE Spagna) hanno permesso di collezionare un notevole numero di esemplari di una nuova specie di foraminifero, che appartengono ad un genere non ancora conosciuto. Studi dettagliati di questi esemplari, basati esclusivamente su sezioni sotttili non orietate, hanno permesso di definire il genere nuovo e la nuova specie che lo rappresenta. La definizione di Praemurgella valenciana nov. gen. nov. sp. assume grande importanza per due motivi. Primo, per un punto di vista sistematico, dato che i caratteri morfologici e strutturali fanno ritenere $P$. valenciana una specie primitiva rispetto a Murgella lata LuperTo SinNi, 1965, dalla quale deriva il nome del genere nuovo. Secondo, per la sua posizione biostratigrafica limitata a pochi metri entro la successione potente e monotona in facies di inner-shelf della piattaforma carbonatica betica, per cui la nuova specie può essere considerata un buon marker cronobiostratigrafico, indicativo di un età Santoniano medio.

PAROLE-CHIAVE: PRAEMURGELLA VALENCIANA NOV. GEN. ET SP., CRETACEO SUPERIORE, PIATTAFORMA CARBONATICA, PREBETICO, SANTONIANO.

\section{INTRODUCTION}

Exhaustive sampling of Coniacian to Santonian shallow marine limestones in the Sierra de la Solana (SE Spain) permitted the collection of a great number of specimens of the new genus and species described in this paper. These rocks belong to the Sierra de Utiel Formation and outcrop extensively in the southeastern part of Sierra de la Solana, near the town of Bocairent (Valencia province) (Fig. 1). In this location, the unit is $240 \mathrm{~m}$ thick and forms an easily recognizable succession 

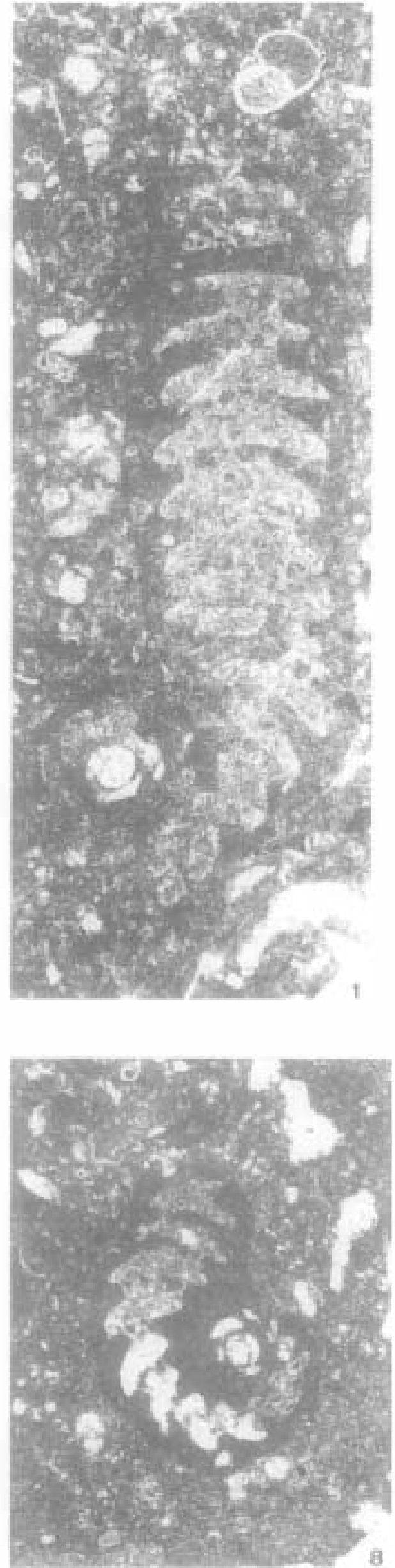
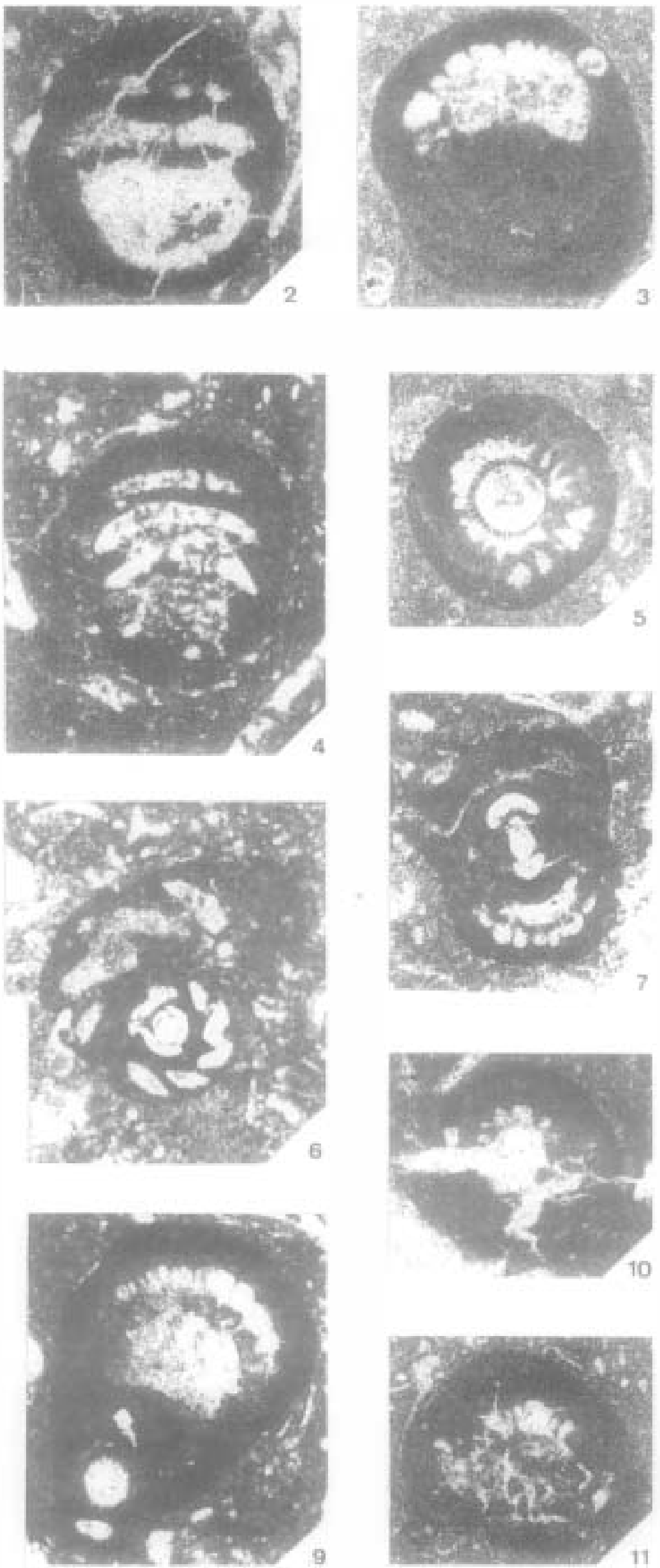

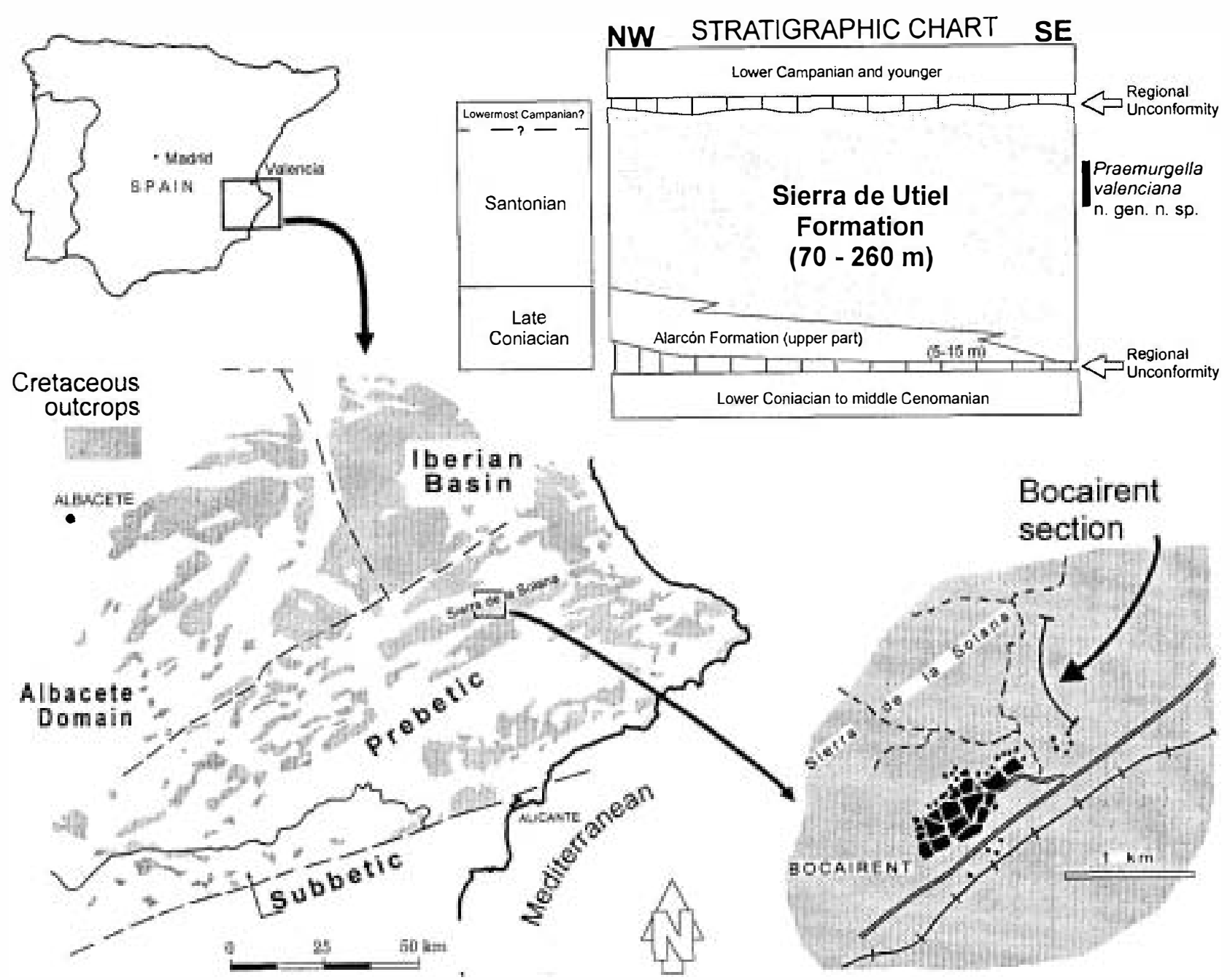

FlgUke 1 - Location of the Bocairent section in the Sierra de la Solana (Valencia Province) showing its position within the Prebetic paleogeographic domain. The chronostratigraphic summary chart in the upper right corner shows the approximate stratigraphic distribution of Praemurgella valenciana nov. gen et sp. Situation géographique et stratigraphique de la coupe de Bocairent dans la Sierra de la Solana (Province de Valence, SE de l'Espagne), montrant la position paléogéographique de cette coupe dans le Domaine Prébétique et la distribution de Praemurgella valenciana nov. gen et sp. dans les carbonates de la Formation Sierra de Utiel.

of more or less pronounced steps in the landscape, capped by thick, cliff-forming carbonates and clastics of Campanian and Maastrichtian age.

The carbonate facies sampled were deposited in the wide carbonate platform of the Betic basin, a thermally subsiding passive continental margin that undergoes its last evolutionary stages before convergence (Martín-Chivelet et al. 1997). Facies range from reefal framestones to intertidal laminated dolomicrites and paleosols. Shallow subtidal biopelmicrites which are dominant throughout, often show rich associations of benthic foraminifers and green algae, considered excellent material for paleoecological and biostratigraphic studies (Luper- to Sinni et al. 1998). The new genus and species comes from these associations.

\section{SYSTEMATICS}

Family MILIOLIDAE Ehrenberg, 1839

\section{Genus Praemurgella nov. gen} Figs 2-3

Type-species - Praemurgella valenciana nov. sp.

Holotype - Subvertical section shown in Fig. 2.1. Sample B078/2.

Derivation of name - The new genus Praemurgella is reminiscent of Murgella LUPERTO SiNNI, 1965 and may be considered its precursor.

FIgure 2 - Praemurgella valenciana nov. gen. et sp. 1. Holotype. Subaxial section, (specimen BO 78/2) $\times 80.2$. Oblique section (spec. BO $75 / 8) \times 80$. 3. Oblique section of uncoiled segment (spec. BO 73/2) $\times 80$. 4. Cortically oblique section (spec. BO $73 / 8) \times 50.5$. Transverse section (spec. BOE 12) x 50. 6. Subequatorial, inclined section (spec. BO 73/6) x 32. 7. Oblique - axial section of coiled segment (spec. BO 75/6) x 0. 8. Subequatorial section, slightly oblique (spec. BO 73/1) x 32. 9. Highly oblique section of coiled stage (spec. BO $75 / 8) \times$ 80. 10. Slightly oblique section of uncoiled segment (spec. BO 75/9) $\times 50$. 11. Oblique section of uncoiled segment (spec. BO 76/5) $\times 50$. 1. Holotype. Section subaxiale (spéc. BO 78/2) × 80. 2. Coupe oblique (spéc. BO 75/8) x 80. 3. Section oblique du stade déroulé (spéc. BO $73 / 2) \times 80$. 4. Section oblique corticale (spéc. BO 73/8) × 50. 5. Section transverse (spéc. BOE 12) x 50. 6. Coupe inclinée subéquatoriale (spéc. BO 73/6) × 32. 7. Section oblique - axiale du stade enroulé (spéc. BO 75/6) × 50. 8. Section subéquatoriale, légèrement oblique (spéc. BO 73/1) × 32.9. Coupe très oblique du estade enroulé (spéc. BO 75/8) x 80. 10. Section légèrement oblique du stade déroulé (spéc. BO $75 / 9) \times 50$. 11. Section oblique de la partie déroulée $($ spéc. BO 76/5) × 50. 

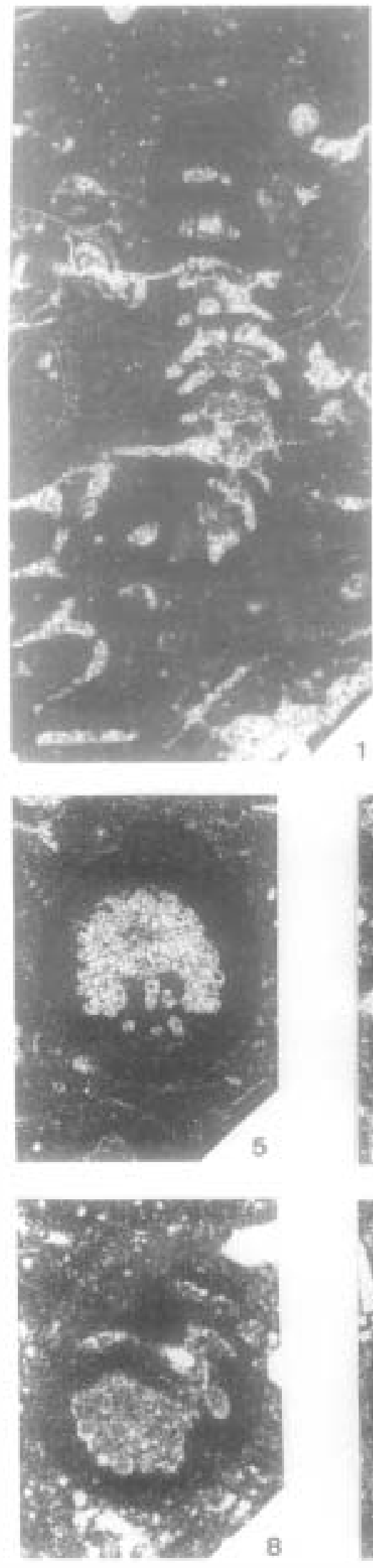
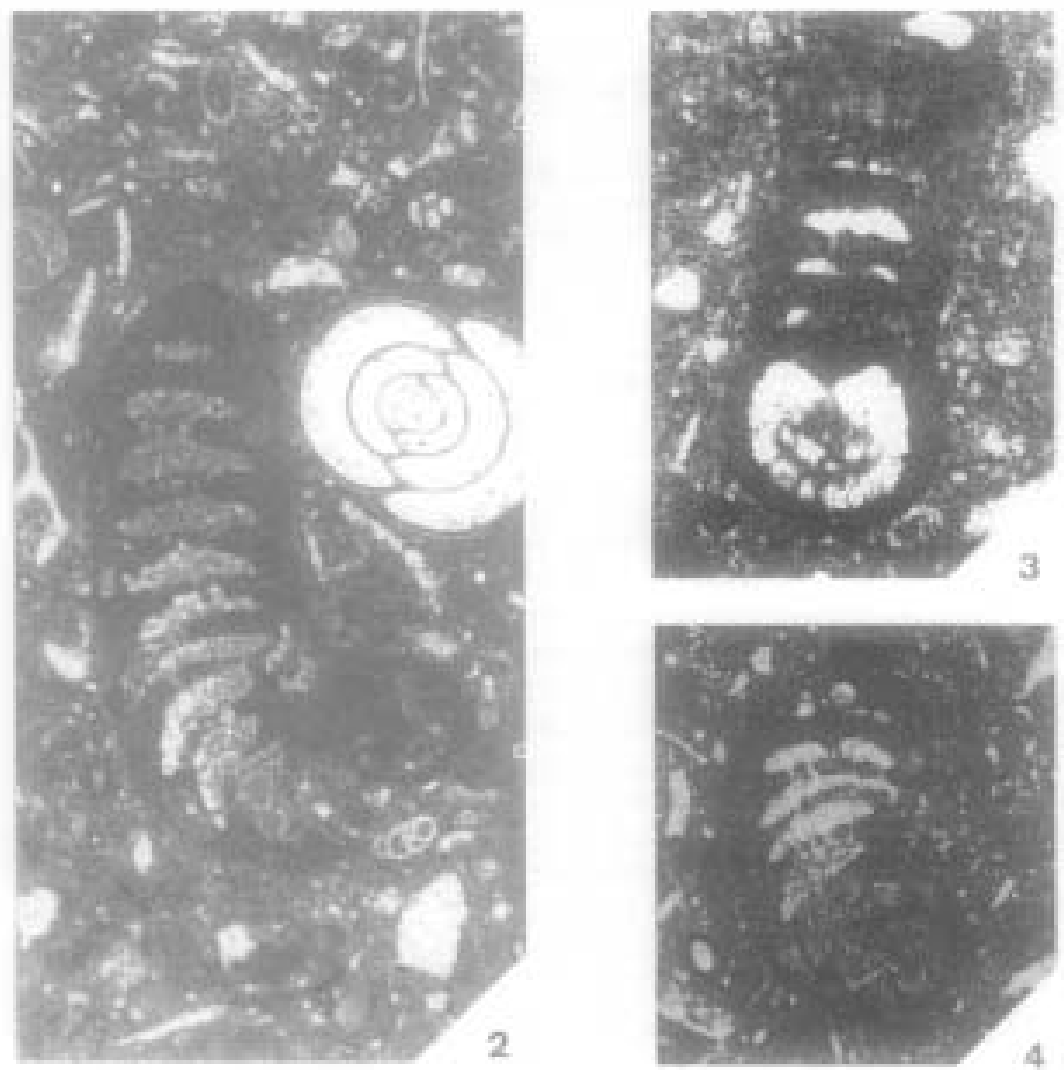
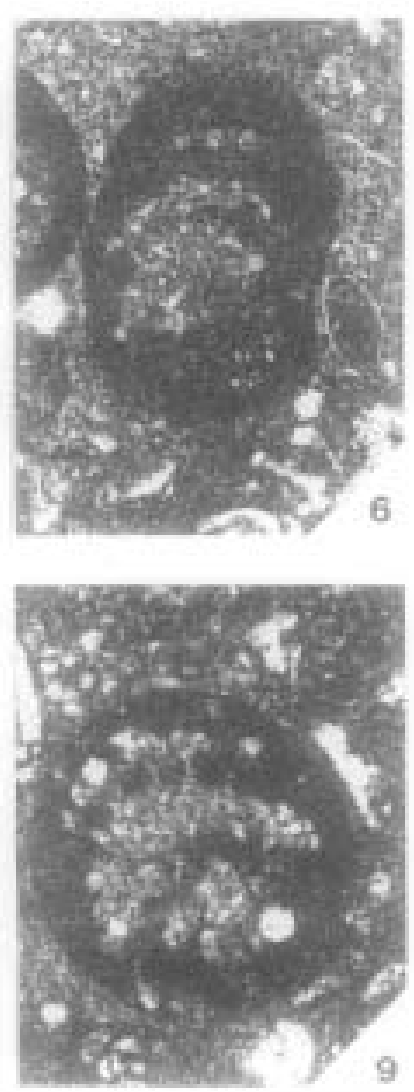

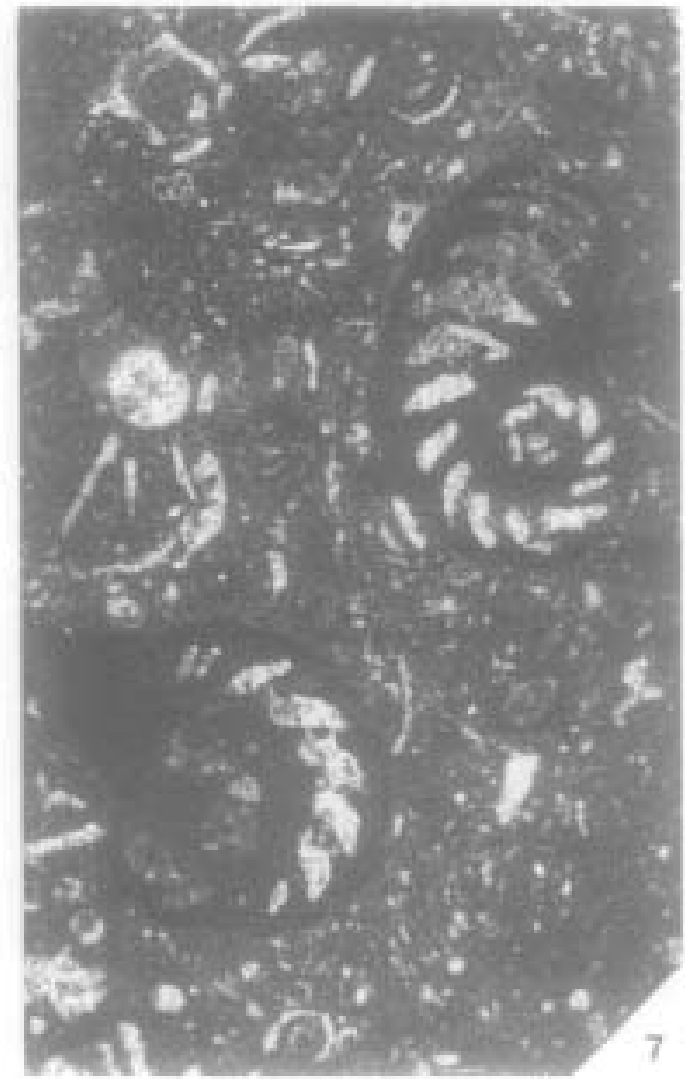

FIGURE 3 - Praemurgella valenciana nov. gen. et sp. 1. Subequatorial inclined section (specimen BOE 12) x 32. 2. Oblique section (specimen BOE 17) $\times 32$. 3. Oblique section of uncoiled segment (specimen BO 74/8) $\times 32$. 4. Oblique section of uncoiled segment (specimen BO 76/a) $\times$ 32. 5. Transverse oblique section (specimen B073/2) x 40. 6. Oblique section of uncoiled segment (specimen BO 77/1) $\times 40.7$. Facies showing Praemurgella valenciana (specimen BOE 15) $\times 32.8$. Oblique section (specimen BO 75/24) $\times 40$. 9. Oblique section (specimen BO 73/10) x 40. 1. Coupe inclinée subéquatoriale (spécimen BOE 12) x 32. 2. Section •blique (spécimen BOE 17) × 32. 3. Section oblique du stade déroulé (spécimen BO 74/8) × 32. 4. Section oblique du stade déroulé (spécimen. BO 76/a) × 32. 5. Coupe transversale oblique (spécimen B073/2) × 40. 6. Section oblique du stade déroulé (spécimen BO 77/1) × 40. 7. Facies à Praemurgella valenciana (spécimen BOE 15) x 32. 8. Section oblique (spécimen BO 75/24) x 40. 9. Section oblique (spécimen BO 73/10) x 40. 
Type location - Sierra de la Solana near the town of Bocairent (Valencia province, Spain). The thin sections described correspond to samples BO73-B080, BOE12-BOE15 and BOE17 from the same outcrop.

Type level - Santonian (probably mid Santonian). Located in the upper middle section of the Sierra de Utiel Formation. This unit has been dated by Martín-Chivelet (1995) as late Coniacian to earliest Campanian.

Experimental material - Several tens of specimens were examined in non-orientated thin section. The thin sections presently form part of the Foraminifera collection of the Departamento de Estratigrafia, Facultad de Ciencias Geológicas, Universidad Complutense, Madrid.

Diagnosis - The test is calcareous, microgranular and porcelaneous. Megalospheric forms show a subspherical initial chamber in contact with a flexostylic canal. No microspheric forms were observed. The proloculus gives rise to a short succession of chambers (one to one and a half whorls) showing a planispiral tendency and some degree of involution. These are continuous with just over half a whorl of planispiral chambers which show a rapid growth rate and mark the transition to a final segment of uniserial, relatively large chambers.

The chambers are initially low and wide but become highly arcuate in the second segment of the test. In the uniserial segment, the chambers attain the shape of a wide flattened dome of circular to elliptical transverse section.

The walls are robust, especially in the areas of articulation between successive chambers.

Apertures are single in the first chambers and multiple in remaining chambers. Multiple apertures are formed by a sieve plate which is thinner than the lateral walls and of sufficient length to practically occupy the entire aperture face.

The endoskeleton is formed by subepidermal septula (perhaps in two orders) and by a few pillars associated with the distal part of the septula.

Generic differences - Praemurgella nov. gen. shows close affinity to the genera Murgella LUPERTo Sinni, 1965 and Scandonea De CASTRO, 1971. The presence of subepidermal septula and numerous pillars within the chambers distinguishes the proposed genus from Murgella. Scandonea comprises two species with features that permit the separation of this genus from Praemurgella. The species Scandonea samnitica DE CASTRO has a proloculus with milioline coiling, rudimentary or absent subepidermal septula, and apertures with trematophores in all the chambers (developing close to and over the tooth in younger specimens). Scandonea mediterranea DE CASTRO is characterized (De Castro 1974) by uniserial chambers containing robust subepidermal septula with small, star-shaped holes in the center in which a trematophore develops.

\section{Praemurgella valenciana nov. sp.} Figs 2-3

Holotype - Subvertical section shown in Figure 2.1. Sample: B078/2.

Paratype - All the specimens shown in Figures 2 and 3 correspond to samples BO73-BO80, BOE12-BOE15 and BOE17 obtained from the same bed.
Derivation of name - The species was named after the place of origin of the specimens: Valencia (E Spain).

External features - All the specimens obtained were megalospheric although the presence of microspheric specimens cannot be ruled out.

Externally, the test is broadly cylindrical and some of the coils are compressed with respect to the axial plane. The relatively small, globose, biumbilicate initial segment shows a flabelliform pattern of growth. Three segments may be identified. The first consists of coiled chambers corresponding to one or one and a half whorls. The chambers are arranged planispirally and partially involute. Less frequently, the coiling axis moves away from its initial position and the chambers form an irregular spiral (Figs 3.1; 3.2). The second segment is short and is represented by close to a whorl of uniseriate chambers arranged planispirally. These are low and wide and highly arcuate. Maximum heights correspond to the outer margin of the test.

The second segment grades into the third uncoiled segment of the test via a few chambers (3 or 4) that rapidly grow in height but still preserve their arcuate form.

This third segment is relatively long (at least double the length of the remaining test). It is comprised of a uniserial succession of 2-3 to 12-13 chambers. The test acquires a broad cylindrical shape when there are many chambers. At times, however, the chambers are compressed with respect to the axial plane and the test shows a flabelliform tendency.

Internal features - The descriptions below correspond to non-orientated thin sections:

Walls - The highly characteristic walls are calcareous, microgranular and porcellaneous, and appear dark under transmitted light. Even in the chambers of the initial stage, they are relatively thick and rapidly attain their characteristic thickness at the end of the transitional segment. In the uncoiled segment, wall thickness increases gradually in successive chambers, where maximum thickness in relation to the area of articulation between successive chambers is attained. It is possible that the presence of a "basal layer" could account for the increase in thickness although this could not be proven.

Proloculus and fexostylic canal - Megalospheric specimens from the central sections (Figs 2.1, 2.6, $2.8)$ show a globular, subspheric proloculus which, in a few cases, is slightly flattened and elliptical in section. The initial chamber is continuous with a flexostylic space which lines the chamber and corresponds to approximately half a whorl. The chambers of the first stage, which are usually planispiral and involute, transgress to form one and a half whorls. In some cases, it is possible to observe that the spiral is not completely flat but irregular due to the movement of the coiling axis away from its initial position (Figs 3.1, 3.2).

Chambers - The chambers are low and wide. In the first segment of the test, their height and width increase gradually. Growth rates increase in 
the second portion marking the transition to the uncoiled stage and the chambers, arranged planispirally, rapidly increase in width and, in one to one and a half whorls, attain the typical width of the uncoiled stage. The height of the chambers increases slowly and differentially: height increments are greater in the axial zone than in the outer margin of the test leading to the arcuate shape of the chambers.

The uncoiled and uniserial portion of the test is formed by a very variable number of chambers ranging from 2-3 to $12-13$. The superimposed chambers show a discretely marked line of suture which may also be absent. In contrast, the articulation surface between successive chambers is very wide. The inner cavity takes the form of a flat, very wide bell and is generally subcircular in section although elliptical sections have been also observed in tests compressed laterally in relation to the axial plane. The shape of the chambers is highly dependent on the state of the walls. These attain maximum thickness at the top, in the area of curvature towards the interior test before the septum, and rapidly become thinner to form the septum itself. Both the width and height of the chambers change slowly once those of the previous chamber in the transition stage have been reached.

Height to width ratios range from 0.2 to 0.4 , although specimens showing elliptical transverse sections may attain a ratio of 0.5 .

Septa - The septa are restricted to the periphery of the chambers, corresponding to the outer margin and are thus continuous with the wide articulation zone within the chamber. The central part of the septum harbors a sieve plate which forms the aperture.

Apertures - A single aperture is found in the first two or three chambers. From here onwards, the aperture becomes multiple and is formed by a sieve plate which overlays the septum margin and is usually thinner than the septum. The pores of the sieve plate are scarce in the first chambers of the involute stage but become more abundant as the chamber increases in size in the late involute and transitional stages. Finally, in the uniserial uncoiled segment, the number of pores increases slowly with the width of the chambers.

Endoskeleton - The peripheral portion of the chamber cavity contains characteristically shaped septula: the distal part (facing the inside of the chamber) is usually concave, with an enhanced curvature. Each septulum is of minimum thickness towards the distal part and thickest towards the top and the bottom of the chamber. For this reason, it is easier to observe the septula in sections oblique to the axis of growth particularly in sections cut below the septum. In the larger chambers, the septula may be assigned to one of two groups according to thickness and length.

Dimensions - The dimensions of the holotype's structures are: height of test, $1.57 \mathrm{~mm}$; diameter of initial planispiral segment, $0.57 \mathrm{~mm}$; diameter of chambers of the uncoiled portion, $0.45 \mathrm{~mm}$.
Other features - Within the chambers of the uncoiled segment of several specimens, elements (always few in number) interpreted as rudimentary pillars were identified in both transverse and longitudinal sections. These were joined to the distal part (towards the center) of some septula (Figs $2.1,2.3,2.4,2.5,2.10 .2 .11 ; 3.1,3.2,3.3,3.4,3.5$, $3.6,3.8,3.9)$.

Species differences - Praemurgella valenciana nov. gen. et sp. has similar morphologic and structural features to Murgella lata LUPERTo SINNI, 1965. Since the new species was defined only on the basis of megalospheric forms, distinction between the two species was made on the grounds of: (1) the absence of pillars within the chambers in $P$. valenciana although, as noted above, a few rudimentary pillars were identified; (2) the shape of the test, which in P. valenciana is only rarely compressed in the axial plane; and (3) the notably smaller size of $P$. valenciana.

Further, $P$. valenciana shows some analogy in structure and wall thickness to Scandonea samnitica De CASTRo and Scandonea mediterranea DE CASTRO although substantial differences serve to distinguish them. Thus, the megalospheric form of $S$. samnitica has a completely involute planispiral test and, in some specimens only, there is a tendency to become evolute in the outer chambers. In axial section, the chambers are of the typical horse-shoe shape, with extremities arched downwards. On the other hand, the species $S$. mediterranea (whose inclusion in the genus Scandonea is at present questionable, Luperto Sinni, in press) has within the skeleton "setti robusti interrotti, nella porzione centrale, da un vano a forma di stella su1 quale si impianta un trematoforo" i.e., robust walls, interrupted in the central portion by a star-shaped hole in which a trematophore is implanted (De Castro 1974, p. 8)

Location - Study samples were obtained from the Sierra de la Solana in the Valencia Province (SE Spain) at a spectacular outcrop of Late Cretaceous shallow marine carbonates, near the town of Bocairent. Analysis of this succession has permitted the authors to notably extend the biostratigraphic record of benthic communities (Foraminifera and green algae) of the Betic carbonate platforms corresponding to the Coniacian to late Maastrichtian interval (Luperto Sinni et al. 1998).

Storage of samples - The thin sections were prepared from numerous samples (BO73-BO80, BOE12-BOE15 and BOE17) obtained from the same bed. These thin sections were deposited in the Departamento de Estratigrafia, Facultad de Ciencias Geológicas, Universidad Complutense de Madrid.

Stratigraphic distribution - Santonian (probably mid Santonian) of the Betic platforms (Mesozoic southern continental margin of the Iberian plate). The age is based on the stratigraphic location of the specimens obtained from the upper mid section of the Sierra de Utiel Formation (MartínChivelet 1995). Other microfossils identified in the samples include: Dicyclina schlumbergeri 
Munier-Chalmas, Cuneolina sp., Moncharmontia apeninica De CASTRO, Nummofallotia apula LUPERTO SINNI, and Rotalia spp. Facies containing $P$. valenciana were interbedded with levels which include Lacazina elongata ovula HotTINGER, DRoBne \& CAUS.

Acknowledgements - This research was partially supported by the project PB 97-0330 of the DGES of Spain. The authors are indebted to Dr. M.B. Hart and Dr. F. Robaszynski for their constructive review of the manuscript. The English was revised by A. Burton.

\section{REFERENCES}

De Castro P. 1971a - Osservazioni su Raadshoovenia VAn DeN BoLD e i suoi rapporti col nuovo genere Scandonea (Foraminifera, Miliolacea).Bollettino della Società naturalisti in Napoli, 80: $161-236$.

---.. 1971b - Osservazioni su Archaias lata (LuPERTo SinNI) Bollettino della Società naturalisti in Napoli, 80: 329-364.

-.--- 1974 - Su alcune nuove miliolidi del Senoniano del Mediterraneo. VI Colloque Africain de Micropaléontologie: 3-19.
LuPERTo Sinni E. 1966 - Nuovo genere di foraminifero del Senoniano delle Murge. Bollettino della Società paleontologica italiana, 4: 263-268.

-----, Giménez R. \& MARTín-Chivelet J. 1998 - Coniacian to lowermost Campanian benthic foraminifers and green algae of the Bacairent section (SE Spain). Biostratigraphic and paleobiogeographic implications. In CAÑAVERAS J.C., GarCía DEL CURA M.A., Soria J. (eds), Sedimentology at the dawn of the third millenum. 15th International Sedimentological Congress Abstracts: 519-520.

MARTIN-ChIVELET 1995 - Sequence stratigraphy of mixed carbonate-siliciclastic platforms developed in a tectonically active setting, Upper Cretaceous, Betic continental margin (Spain). Journal of Sedimentary Research, B65: 235-254.

..---, Giménez R. \& LuPERTo Sinni E. 1997 - La discontinuidad Companiense basal en el Prébético: Inicio de la convergencia alpina en la Margen Betica ? Geogaceta, 2: 121-124.

\section{E. LUPERTO SINNI}

Dipartimento di Geologia e Geofisica

Università di Bari

Via E. Orabona. 4

I-70125 Bari

\section{J. MARTÍN-CHIVELET \& R. GIMÉNEZ}

Departamento de Estratigrafia

Instituto de Geologia Económica (CSIC-UCM)

Facultad de Ciencias Geológicas E-28040 Madrid 